Bente Lihn Jensen, Iфrn Korzen \& Gunver Skytte*

\title{
Spørgsmål og svar \\ - komparativt dansk-italiensk
}

\section{Indledning}

Den problemstilling der fremlægges i nærværende artikel, indgår som en del af et større problemkompleks i forskningsprojektet Italiensk sprogbrug ${ }^{1}$, nemlig forsøget på at bestemme og definere afgrænsningskriterier for større sammenhængende tekstenheder eller tekstsekvenser over sætningsniveau, der kan danne grundlag for komparativ interlingvistisk beskrivelse af sprogbrug ${ }^{2}$.

Svaret, der i traditionel grammatik er en oftest overset eller i det mindste stedmoderligt behandlet sproglig struktur ${ }^{3}$, viser sig i ovennævnte sammenhæng at være en relevant og interessant genstand for beskrivelse. Vi ønsker i denne artikel at argumentere generelt for at fortolke spфrgsmål og svar som en strukturel enhed, der syntaktisk er sammenlignelig med en kompleks satning. Dette ses specielt i komplekse sætninger med anaforisk henvisning, som fx

1 Et af de fem projekter inden for programmet Lingvistik og fremmedsprog, der blev igangsat af Statens Humanistiske Forskningsråd i 1993. For en præsentation af projektet henvises til Skytte/Jensen/Korzen (1993).

2 For tidligere diskussion af emnet henvises til Jensen/Korzen/Skytte (1995) og Korzen (1997). Sml. endvidere Gil (1995), der påpeger og diskuterer den metodiske nødvendighed af at operere med en "Texteinheit" som analyseenhed ved en tekstlingvistisk (og i det pågældende tilfælde komparativ) beskrivelse.

3 Når svaret så godt som ikke forekommer i grammatikker, hænger det utvivlsomt sammen med, at det stort set er et talesprogsfænomen, mens grammatikker overvejende beskriver skriftsprogsfænomener.

* Bente Lihn Jensen, I $\phi r n$ Korzen Afd. for Italiensk

Handelshфjskolen i Kфbenhavn

Dalgas Have 15

DK-2000 Frederiksberg
* Gunver Skytte

Romansk Institut

Kфbenhavns Universitet

Njalsgade 80

DK-2300 København $S$ 
(1) a Jeg har set kongen, det har jeg.

- Har du set kongen? - Ja, det har jeg.

b Jeg har set kongen, og det har Peter også.

- Har du set kongen? - Ja, og det har Peter også.

c Jeg kommer i morgen, og det gør Peter også.

- Hvem kommer i morgen? - Det gør Peter.

Ideelt kan spørgsmål - svar således anskues som et interaktionelt samarbejde omkring sætningsstrukturering og opbygning af information. I normal sprogbrug vil spфrgsmål-svar typisk bestå af flere sætninger eller sætningsemner, men med semantisk og informationsstrukturel sammenhæng som $\mathrm{g} ø \mathrm{r}$ det berettiget, ifølge vore analyser, at betragte dem som eksempler på tekstsekvenser.

For at underbygge fortolkningen af spørgsmål-svar som en kompleks sætning vil vi påvise en række sprogspecifikke overensstemmelser, som i eks. (1), mellem strukturering af den komplekse sætning (med anaforisk henvisning) og strukturering af spørgsmål-svar. De specifikke overensstemmelser gælder intralingvistisk, mens det er fælles $i$ hvert fald for germanske og romanske sprog - at der er strukturel lighed mellem de pågældende sætningsstrukturer. Ud over anaforer drejer det sig om fænomener som brug af vikarverber, kontrol, rektion, kongruens og ellipse ${ }^{4}$. De interlingvistiske forskelle mener vi kan henføres til generelle sprogtypologiske træk.

Sprogdidaktisk vil vi pege på det nyttige $\mathrm{i}$ at kunne give grammatiske regler ikke blot for grammatikalsk korrekt strukturering af spørgsmålet, men også af svaret, samtidig med at indlæringen af og forståelsen for disse regler fremmes ved den påpegede parallel til den anaforiske sideordningskonstruktion.

For tekstsekvensen bestående af spørgsmål-svar-enheden vil vi påvise de sproglige træk der er medvirkende til at skabe informationssammenhængen (forskellige kohæsions- og kohærensfænomener som topisk kontinuitet, reformulation etc.).

4 Betegnelsen rektion anvendes her for at angive det syntaktiske forhold mellem en styrende og en styret størrelse, som fx mellem præpositional og regimen eller styrelse. - Betegnelsen kontrol bruges for at angive antecedenten for et ikke udtrykt subjekt ved infinitte former (undertiden benævnt "logisk subjekt"). - For en kritisk vurdering af ellipse-begrebet, specielt med henblik på ellipsens funktion i diskursperspektiv, henvises til Cherchi (1985). 
Vi henviser til tidligere artikler (Skytte 1995a, Skytte 1995b og Skytte 1996), hvor vi har diskuteret en række arbejder, der er af teoretisk interesse for vores emne. Vi henviser specielt til Diderichsen (1962), Jensen (1970), Halliday/Hasan (1976), og Salvi/Vanelli (1992).

En udførlig og udtømmende fremstilling af emnet spфrgsmål-svar i komparativt perspektiv dansk-italiensk er ikke mulig inden for rammerne af nærværende arbejde. Vi vil derimod koncentrere os om at fremlægge og diskutere problemstillinger af principiel karakter med henblik på en senere mere udførlig fremstilling. Det drejer sig om følgende emner:

Struktur (specielt med henblik på anafor- og ellipsefænomener o.l.)

Modalitet (idet svaret ved $J a / n e j$-spørgsmål fortolkes som modalitetsmark $\varnothing \mathrm{r}$ i forhold til den i spørgsmålet indeholdte proposition) ${ }^{5}$

\section{Spørgsmål-svar-konstruktionen set som tekstsekvens.}

\section{Struktur}

Spørgsmålet præsupponerer svaret (ligesom svaret præsupponerer et spørgsmål), og spørgsmålets struktur præsupponerer svarstrukturen ${ }^{6}$. Dette afspejler sig på forskellig måde såvel i spørgsmålets som i svarets sproglige struktur. I de to basale spørgesætningstyper ja/nej-spфrgsmålet $(J / N)$ og $x$-spфrgsmålet $(X)$ afspejler det sig for $J / N$ på dansk ved ordstilling (inversion) og på italiensk i talesproget ved intonation (stigende), og i skriftsproget ved interpunktion (?). I de tilfælde hvor svaret på $J / N$ indholdsmæssigt drejer sig om sandhedsvardien af den $\mathrm{i}$ spørgsmålet indeholdte proposition (se note 5 samt afsn. 3), medfører

5 Cf. Lyons (1995:254): "When one asks a neutral [...] question, one expresses a proposition and simultaneously expresses one's attitude of non-commitment with respect to its truth-value. But there is more to it than this. [...] To ask a question [...] is not merely to express the propositional attitude of non-commitment - that is, to pose the proposition as a question - but also, in so doing, to indicate to one's addressee - prosodically, paralinguistically or otherwise - that one desires them to resolve one's uncertainty by assigning a truth-value to the proposition in question."

6 Vores brug af termen prasupposition afviger her fra den gængse anvendelse (= ikke ekspliciteret viden der forudsættes bekendt for modtager), men er fx i overensstemmelse med Halliday's udvidede anvendelse af begrebet (= diskurselementer, herunder også 'clauses' som spørgsmål og svar, der forudsætter hinanden) i forbindelse med kohæsionsrelationer (Halliday/Hasan, 1976:4). 
det, at spørgsmålet ikke kan indeholde modale udtryk der vedrører belagget ${ }^{7}$, cf.

(2) *Kommer Peter formodentlig i morgen?

Sådanne modale udtryk kommer derimod til udtryk i svaret, som fx

(3) - Kommer Peter i morgen?

- Ja, formodentlig.

Dette træk understreger opfattelsen af spфrgsmål-svar som en kompleks sætning, idet de modale udtryk i svaret ja og formodentlig vedrører den i spørgsmålet indeholdte proposition.

$X$ er en kataforisk størrelse der forudsætter en størrelse i svaret (remaet i den komplekse sætning), samtidig med at det indeholder visse formelle oplysninger (fx ordklasse, køn, tal, syntaktisk funktion, +/animeret). En udtømmende komparativ fremstilling bør omfatte en oversigt over $X$-inventaret i de respektive sprog der sammenholder disse formelle oplysninger. Det falder imidlertid også uden for rammerne af nærværende lille artikel.

Svarets strukturmuligheder kan inddeles i følgende hovedtyper på dansk og italiensk. Til flg. danske $J / N$ og $X$ :

(4) Har du spist æblet?

(5) Hvem har spist æblet?

svarer:

(4a) 1. Ja. (Ren sandhedsværdi)

2. Ja, det har jeg. (Anaforisk svar)

3. Ja, jeg har. (Elliptisk svar)

4. Ja, jeg har spist æblet. ("Fuldt" svar)

(5a) 1. Peter. (Elliptisk svar - rema)

2. Det har Peter. (Anaforisk svar)

3. Det har Peter gjort. (Anaforisk svar + vikarverbum)

4. Det har Peter spist. (Anaforisk svar)

5. Peter har spist æblet. ("Fuldt" svar)

og til flg. italienske $J / N$ og $X$ :

(6) Hai mangiato la mela?

(7) Chi ha mangiato la mela?

7 Cf. Jensen (1997) og note 14.

8 Dette er dog acceptabelt i ekko-spørgsmål eller i særlige dialogsammenhænge. 
svarer:

(6a) 1. Sì. (Ren sandhedsværdi)

2. Sì, l'ho mangiata. (Anaforisk svar)

3. Sì, ho mangiato la mela. ("Fuldt" svar)

(7a) 1. Pietro. (Elliptisk svar - rema)

2. L'ha fatto Pietro. (Anaforisk svar + vikarverbum)

3. Pietro l'ha mangiata. (Anaforisk svar)

4. Pietro ha mangiato la mela (med prosodisk fremhævelse af Pietro). ("Fuldt" svar)

Det bemærkes at de anaforiske svartyper på henholdsvis dansk og italiensk afviger fra hinanden m.h.t. det element anaforen erstatter - i (4a/2): da. prædikatet (hjælpeverbet forbliver som tempusmarkør), i (5a/4) og (6a/2): da. og it. objektet - ligesom den danske elliptiske svartype (4a/3) ikke er mulig på moderne italiensk (se note 11). Vedr. (7a/2), se nedenfor.

Diderichsen (1962:153) gør opmærksom på udeladelser i svar og tilføjer: "Hvis man svarer med en fuldstændig Sætning, virker det oftest understreget pertentligt." Man kunne på den baggrund foreslå at betegne det fulde svar som markeret fordi det både udtrykker sandhedsværdien af propositionen og gentager denne.

Imidlertid rejser der sig her nogle spørgsmål dels vedrørende anvendelse af begrebet markering, dels af komparativ interlingvistisk art, som det er nødvendigt først at afklare.

Begrebet markering har sin oprindelse i strukturalismens klassifikation af det fonologiske og morfologiske materiale i bincere oppositioner, hvoraf den ene størrelse siges at være markeret $\mathrm{i}$ forhold til den anden umarkerede ( $\mathrm{fx}$ stemthed vs ustemthed; pluralis vs singularis etc.). Termen overføres ofte til andre områder, men får en mere vag betydning i tilfælde hvor der ikke foreligger en entydig binær opposition ${ }^{9}$. Det er derfor nødvendigt at gøre rede for hvad man mener, når man taler om et markeret eller umarkeret svar.

Inden for pragmatisk lingvistik anvendes begrebet markering ofte $\mathrm{i}$ forbindelse med svarets adakvans, dvs. det forhold at svaret indholdsmæssigt opfylder spørgers forventning om at få svar på sit spørgsmål. I

9 Det er netop tilfældet med propositionen, der ikke indgår i en klasse af binære enheder, cf. Benveniste (1966:129). 
henhold til denne definition er samtlige de citerede svartyper umarkerede (adcekvate), mens et svar på spørgsmål (4) og (5) som fx

(4b)/(5b) To og to er fire

ville blive betegnet som markeret (ikke-adakvat). For klarhedens skyld vil vi nedenfor bruge betegnelserne adakvat - ikke-adakvat på denne måde.

Herudover kan vi forestille os to forskellige måder at anvende begrebet markering på i forbindelse med svar, nemlig a) som ovenfor omtalt med henblik på strukturen, hvorefter det fulde svar må betegnes som markeret, eller b) frekvens. Denne sidste form for anvendelse er ikke uinteressant for et projekt der beskæftiger sig med sprogbrug. Ud fra en dansk sprogbrugers intuition ville man nok fortsat anse det fulde svar for markeret og de $\varnothing$ vrige for umarkerede idet svartype 2, det anaforiske svar, formodentlig er det hyppigste mens 3, det elliptiske svar, forekommer let markeret (?) med fokalisering på verbalindholdet. Cf.:

(8) - Kender I hinanden?

- Ja.

- Ja, det gør vi.

- Ja, vi gør.

(9) - Kan du se den her?

- Ja.

- Ja, det kan jeg.

- Ja, jeg kan.

Ved $X$-spørgsmål er svartype 2, det anaforiske svar, meget almindeligt hvis $X$ er prædikat eller subjekt:

(10) - Hvem er den dame?

- Det er min søster.

hvorimod det elliptiske svar er almindeligst i andre tilfælde:

(11) - Hvor bor du?

- I København.

(12) - Hvorfor har du så stor en mund?

- For at jeg bedre kan spise dig.

Imidlertid synes forholdet ikke at være helt parallelt på italiensk. Det fulde svar synes i mange tilfælde at ækvivalere med det danske umarkerede svar. Bruges det markeret, vil der normalt være ledsagende 
fænomener som modalitetsmarkører eller prosodiske markører, som angiver markeringen. Cf. flg. autentiske eks. på spørgsmål-svar:

(13) - E sei in affitto?

- Sì, sono in affitto. (Scene, p. 31)

(Da.: - Bor du til leje? - Ja, det gør jeg)

(14) - Dove abiti?

- Io abito vicino al centro. (Scene, p. 7)

(Da: - Hvor bor du? - Inde ved centrum).

Mindre frekvent er svartype 1:

(15) - È nuova questa casa?

- Sì. (Scene, p. 31)

og det er utvivlsomt bedst at anbefale learnere af italiensk som fremmedsprog den fulde svartype. Cf. endvidere følgende eks. på svartype 3 med let markering:

(16) - Sei sposato?

- No, no, non sono sposato. (Scene, p. 8) ${ }^{10}$

(17) [B: Ma, è successo che un boss mafioso era ricoverato in ospedale ed ha potuto andarsene.]

A: È scappato dall'ospedale?

B: È scappato dall'ospedale! (Scene, p. 36) (med prosodisk markering).

Den påpegede forskel mellem dansk og italiensk bliver tydelig ved oversættelser, cf.:

(18) "A me farebbe piacere che tu li [articoli] scrivessi. Ma se non te la senti..."

- "Ti farebbe piacere?"

- "Sì, mi farebbe piacere.” (Moravia, p. 88)

"Jeg ville blive glad, hvis du skrev dem. Men, hvis du ikke har lyst..."

- "Det ville glæde dig?"

- "Ja, det ville glæde mig." (Da. oversættelse, p. 79).

Den danske oversættelse bliver "transparent", dvs. den afspejler originalsprogets struktur, mens den “ækvivalente” danske svarstruktur ville være:

10 Den adspurgte unge mand er ikke i den normale giftefærdige alder, og såvel intonationen som den mimik der kan iagttages på videoen, understreger markeringen. 
(18a) Ja, det ville (det).

I det følgende skal vi ved en række eksempler illustrere nogle typiske ellipse- og substitutionsfænomener ved svartype 2-3 på henholdsvis dansk og italiensk. Det gælder generelt, at de for det enkelte sprogs vedkommende svarer til de substitutionsfænomener, der er mulige i komplekse sætninger med anaforisk sideordning, som vist i eks. (1) i indledningen.

Udeladelse af perfektum participium eller brug af anaforisk henvisning i sammensat tid:

(19) - Har Peter spist?

- Ja, han har/det har han.

Cf. italiensk: - Pietro ha mangiato? - *Sì, (lo) ha. ${ }^{11}$

Udeladelse af infinitiv eller brug af anaforisk henvisning efter modalverbum:

(20) - Skal du arbejde?

- Ja, jeg skal/det skal jeg.

På italiensk eksisterer denne mulighed også, men med begrænsninger i forhold til dansk som os bekendt ikke er udførligt beskrevet, og som vores eget materiale heller ikke er tilstrækkeligt til at belyse. Svarende til eks. (20) vil udeladelse af infinitiv på italiensk være mindre acceptabelt (måske p.g.a. gentagelse af samme modalverbum):

(21) - Devi lavorare?

- *Sì, devo/??Sì, lo devo.

Men: - Sì, ma non posso.

Nægtelse, sammensat tid og modalverbumsskift synes at være faktorer, der muligg $\varnothing r$ absolut brug af modalverbet:

(22) - Mi potresti menzionare il nome di una città danese?

- No, non posso/No, non voglio.

(23) - Perché hai smesso di fumare?

- Perché ho dovuto.

11 Denne form for ellipse er derimod mulig i ældre italiensk. Cf.:

Siro: "Avete voi, per questo, tentato per ancora cosa alcuna?" - Callimaco: "Sì, ho, ma piccola cosa." (Machiavelli, La Mandragola, p. 26). 
Brug af verbum vicarium (da. gфre, ital. fare): også her er der begrænsninger på italiensk i forhold til dansk ${ }^{12}$ :

(24) - Tror du på ham?

- Nej, det gør jeg ikke.

(25) - Ti fidi di lui?

- *No, non lo faccio.

På italiensk er muligheden begrænset til verba actionis (Renzi 1988: 83-84):

(26) - Hai pagato il tassì?

- Sì, l'ho fatto.

(27) - Chi ha pagato il tassì?

- L'ha fatto Pietro.

Rektion: I danske $X$-svar kan præpositionen udelades i svartype 1:

(28) - Hvem har du talt med?

- Peter./Med Peter.

Derimod synes det ikke at være muligt på italiensk:

(29) - Con chi hai parlato?

- ??Pietro./Con Pietro.

Kontrol: synes at gælde for begge sprog, cf.:

(30) - Hvad laver du?

- Tæller penge.

(31) - Che cosa bisogna fare con Craxi?

- Dimenticarlo. (Corriere della Sera, 1.10.1995).

I eks. (30) og (31) bemærkes iøvrigt brugen af verbum vicarium i spørgsmålet sammen med interrogativt pronomen med verbum som forventet rematisk svar.

Kongruens:

(32) - Hvilket hus er størst?

- Det røde.

(33) - La casa più bella, qual è?

- Quella rossa.

12 Der er iøvrigt også begrænsninger på dansk. En diskussion heraf vil imidlertid føre for vidt inden for rammerne af nærværende artikel. 


\section{Modalitet}

I det foregående afsnit har vi argumenteret for at spørgsmål-svar syntaktisk set kan opfattes som en kompleks sætning. I dette afsnit vil vi argumentere for at der også ud fra den semantisk-pragmatiske synsvinkel der vedrører modalitet, er belæg for at opfatte sekvensen som en enhed.

Med modalitet menes den del af en ytring der i modsætning til propositionen er relateret til afsender ${ }^{13}$ : primært dennes intention med kommunikationen, kaldet sproghandling, samt hans forholden sig til det propositionelle indhold i ytringen - først og fremmest belægget ${ }^{14}$.

Opfattes spørgsmål-svar som én sproghandling, hvilket eksplicit siges i bl.a. Searle (1975), er det spørgsmålet der angiver sproghandlingen og svaret der viser graden af vellykkethed (eng. felicity), herunder ytringens sandhedsværdi. Som understøttelse for denne opfattelse kan anføres at et spørgsmål der ikke besvares, ikke opfattes som et afsluttet hele. Det betyder dog ikke at spørgsmål og svar nødvendigvis skal følge umiddelbart efter hinanden, hvilket følgende eksempel illustrerer. Her adskilles det første spørgsmål fra sit svar af et spørgsmål fra Jacob, der ikke uden videre kan se det relevante i spørgsmålet og derfor ikke ønsker at samarbejde (der tænkes her på de maximer der er opstillet for god kommunikativ adfærd i Grice (1975)), og af endnu et spørgsmål fra Bella der besvares i og med at Jacob besvarer det første spørgsmål (se endvidere afsn. 4.2):

13 Om modalitet generelt se Jensen (1997). Følgende eksempel kan tjene som illustration af det der indgår i modalitet (eller modalitetskomponenten) og som står i modsætning til propositionen - der i dette tilfælde er [[stjæle (Peter, en cykel)]fortid i forhold til kommunikationstidspunkt]

Jeg ser mig nødsaget til at fortælle dig at jeg desværre med mine egne øjne har set at Peter stjal en cykel.

Her angiver fortcelle sproghandlingen, Jeg ser mig nфdsaget til afsenders forholden sig til modtager, med mine egne фjne har set afsenders kilde, fortidsformen stjal i kombination med kildeangivelsen angiver at afsender opfatter sagsforholdet som faktuelt, hvilket vedrører sandhedsværdien i ytringen, og endelig kan desvarre angive afsenders holdning til det propositionelle indhold.

14 Belæg dækker sandhedsværdi og kilde, jf. note 13. 
(34) Bella: Hvor bor du?

Jacob: Hvorfor vil du vide det?

Bella: Ka' man overhovedet ikke tale med dig? Jacob: Jeg bor ingen steder.... [spørgsmål1]

[spørgsmål2]

[spørgsmål3]

[svar3 implicit + svar1 eksplicit]

(Bella 22)

Af pladshensyn vil vi her kun beskæftige os med de spørgsmål der sproghandlingsmæssigt fungerer som spørgsmål, hvormed menes at afsender ønsker en sproglig respons fra svarer.

Inden for sproghandlingen Spørgsmål skelner vi mellem 3 typer talehandlinger ${ }^{15}$, der adskiller sig fra hinanden mht den sproglige information spørger $\emptyset$ nsker af modtager. De tre talehandlinger kan med Togeby (1993) parafraseres på følgende måde:

1. Giv oplysninger om den størrelse der står i fokus. Sprogligt udtrykkes denne talehandling ved X-spørgsmål, jf. (35). Det adækvate svar uden forbehold (jf. Figur 1) er her ét i form af faktuel oplysning om det $\emptyset$ nskede element:

(35) - Hvem har du talt med?

- Peter.

\section{Oplys mig om det i spørgsmålet indeholdte sagsforhold er/bliver et positivt eller negativt faktum:}

(36) Er Peter syg? = Er Peter syg eller er Peter ikke syg?

(37) Pietro è malato, sì o no?

De adækvate svarmuligheder uden forbehold er her: $J a$ eller $N e j$ på dansk, Si eller No på italiensk (dog med de begrænsninger der er omtalt i afsn. 2).

På udtrykssiden er der som tidligere nævnt tale om et J/N-spørgsmål, men da der til dette udtryk svarer to forskellige typer talehandling, foretrækker vi at kalde denne form for talehandling for et Enten-Ellerspørgsmål. Denne talehandling kommer sprogligt til udtryk i J/Nspørgsmål der er er positivt udformet, hvorimod et negativt udformet spørgsmål basalt set opfattes som det vi vil kalde et Enighedsspфrgsmål (se følgende type).

15 Searle (1975) skelner mellem illocutionary act der svarer til sproghandling, og speech act der svarer til talehandling. Eksemplificering af denne forskel findes bl.a. i Lundquist (1983). 
3. Bekræeft hvis du kan, min opfattelse af et sagsforhold. Sagsforholdets sandhedsværdi opfattes af spørger som værende positiv i:

(38) - Du kommer i aften, ikk?

- Jo, det gør jeg da.

(39) - Vieni stasera, eh?

- Certo./Ma certo./Come no.

og som negativ i:

(40) - Peter er ikke syg, vel?

- Nej, det er han da ikke.

(41) - Ma Pietro non è malato, vero?

- No no.

Denne form for talehandling vil vi kalde for Enighedsspфrgsmål ${ }^{16}$. Dette er der kun ét uforbeholdent adækvat svar på som anført i ovenstående eksempler.

På såvel dansk som italiensk kan Enighedsspørgsmål udtrykkes med tag question ${ }^{17}$ (i Cramer et al. (1996) foreslås det at kalde denne spørgeform for påhangsspфrgsmål på dansk) som ovenstående eksempler viser. På dansk kan man tillige bruge J/N-spørgsmål:

(42) Kommer du ikke i aften?

hvilket derimod kun i visse tilfælde er muligt på italiensk ${ }^{18}$. Ud fra et sprogdidaktisk synspunkt er dette et vigtigt aspekt. Negativt udformede J/N-spørgsmål kan dog også benyttes på en anden måde:

(43) Kommer du ikke i aften? ${ }^{19}$

(44) Er Peter ikke rask?

(45) Pietro non sta bene?

Forskellen mellem (42) og (43) beror på negationens scope. I et spørgsmål af typen

(46) Er du ikke hjemme?

16 Det er i litteraturen udbredt at tale om agreement/disagreement, se fx. Shopen (1975), på italiensk accordo/disaccordo, bl.a. GGIdC vol. III, cap. IV.

17 Dvs. fremsættende sætning eftersfulgt af fx ikk? vel? på dansk og eh? vero? på italiensk

18 I GGIdC III, p. 213 anføres det at J/N i denne betydning kun bruges i tilbud.

19 Fremhævelsen angiver stærktryk. 
kan negationen have scope enten over hjemme og spørgsmålet kan i så fald grosso modo ændres til Er du ude? (ikke-hjemme = ude), eller over den resterende sætning. I sidste tilfælde fungerer negationen ikke som logisk negation, den har udelukkende pragmatisk funktion.

Pladsen tillader os desværre ikke at gå i dybden med det negativt udformede $\mathrm{J} / \mathrm{N}$-spørgsmål, men såvel intra- som interlingvistisk rummer denne spørgeform modalitetsmæssigt flere spændende aspekter hvoraf vi ikke vil undlade at nævne at netop i forbindelse med denne udtryksform synes italiensk at have antydninger af et enighed/uenighedssvarmønster i svarordene, som illustreret i (45a') og (45b'), hvormed menes at svarordet bruges til at udtrykke enighed/uenighed med spørger i relation til en negativt udformet proposition [non stare bene (Pietro)]:

(45a) No (Pietro non sta bene)

(45b) Ma sì (Pietro sta bene).

(45a') Sì (Pietro non sta bene)

(45b') Ma no (Pietro sta bene).

Derimod vil svarordet på dansk, og det kan det også på italiensk (jf. (45a) og (45b)), vedrøre en positivt udformet proposition [stare bene (Pietro)]. En forskel der er vigtig at gøre opmærksom på i sammenligningen af de to sprog.

I spørgsmål-svar er det som nævnt spørger der spiller ud med sit spørgsmål i forventning om at modtager er i stand til at indfri hans forventninger. Set fra spørgers side er det mest adækvate svar derfor typisk det der uden forbehold af nogen art giver ham det ønskede svar. Men i mange tilfælde ser modtager sig ikke i stand til at komme spørger så betingelsesløst i møde når han samtidig skal leve op til kravene om ærlighed og relevans ${ }^{20}$.

Det hyppigst forekommende forbehold går på sandhedsværdien vedr. det propositionelle indhold. Hermed menes forbehold der vedrører svarers egen manglende sikre viden om sagsforholdet, som han derfor ikke ser sig i stand til at gøre til et faktum men vælger at fremstille som et ikke-faktum, dvs. som noget non-faktuelt. Graden af sandsynlighed for realisering er varierende. En diskussion af hvor mange forskellige grader det sprogligt er muligt at udtrykke, ligger uden for rammerne af denne artikel, men de forskellige svarmuligheder kan placeres på en skala, som illustreret i Figur 1.

20 Der tænkes her på Grice’s maximer, Grice (1975). 
Figur 1 Eksempler på forskellige svars sandsynlighedsgrad og deres retning 21 i relation til spørgsmålet Er Peter syg?/ Pietro è malato?

\section{DANSK}

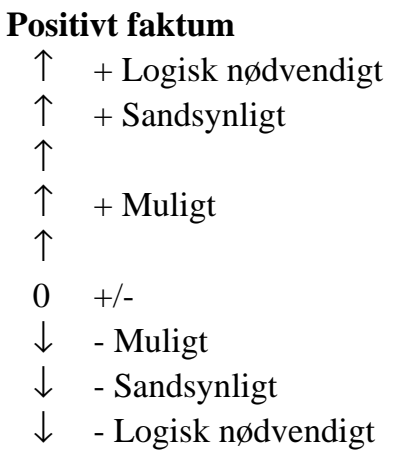

Negativt faktum
Ja, det er han.

Ja, det må han være.

Ja sandsynligvis.

$\mathrm{Ja}$, det tror jeg.

$\mathrm{Ja}$, vist nok.

Ja, måske.

Tja./Nja./Det vides ikke.

Nej, vist nok ikke.

Nej, sandsynligvis ikke.

Nej, det kan han ikke være.

Nej, det er han ikke.
ITALENSK

Sì, è malato.

Sì, dev'esserlo.

Probabilmente sì.

Credo di sì.

Può darsi.

Forse.

Chissà./Nì.

Credo di no.

Probabilmente no.

No, è impossibile.

No, non è malato.

Som det fremgår er eksemplerne Enten-Eller-svar på $\mathrm{J} / \mathrm{N}$, men alle tre typer svar kan modificeres på samme måde:

(35a) - Vist nok Peter.

(38a) - Jo måske.

(42a) - Nej sandsynligvis ikke.

(7a') - Forse Pietro.

(39a) - Probabilmente no.

(45a) - Forse, non lo so.

Når de sandhedsophævende størrelser bruges i svar på X-spørgsmål, er det ikke udsagnet i sin helhed der gøres non-faktuelt, men kun den størrelse der svarer til X i spørgsmålet. Modifikativer af den i Figur 1 nævnte type hører med til nukleardelen af svaret (herom mere i afsn. 4), som snart indeholder det prototypiske svarord $\mathrm{J} / \mathrm{N}+$ modifikativ, som i (47)

(47) Børsens Nyhedsmagasin: Overophednings-scenariet ligger ikke lige for?

Palle Simonsen: Nej, det er ikke sarlig realistisk, men der er en smule usikkerhed. Den finanspolitiske lempelse vil ikke i sig

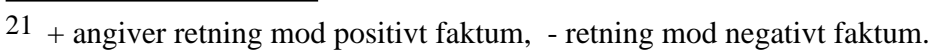


selv bidrage til overophedning. Men om en konverteringsbølge i kombination med lempelsen vil give et stærkere opsving end forventet er umuligt at sige i dag. (Børsens Nyhedsmagasin 11.2.1994)

snart kun modifikativ:

(48) A: Abita vicino alla stazione, a una stazione della metropolitana?

B: Diciamo relativamente vicino, sono 8-10 minuti a piedi per arrivare alla metropolitana. (Scene, p. 15)

Indtil nu har vi set på eksempler hvor modtager tager forbehold i sit svar. I det følgende skal vi kort se på et eksempel hvor det modsatte er tilfældet. Ud fra en overfladisk betragtning ser det i (49) ud som om modtager svarer på andet og mere end han er blevet bedt om; men egentlig er der blot tale om at svarer samarbejder så godt at han "tager ordet ud af munden" på spørger. Grunden til at spørger benytter et spørgsmål som (49) kunne vel tænkes at være at han ikke vil lade svarer tabe ansigt ${ }^{22}$, hvilket der er risiko for hvis han ikke har kendskab til det sagsforhold propositionen beskriver: spørgsmålet vedrører med andre ord afsenders forhold til modtager, et aspekt der vedrører modalitetskomponenten. Kender modtager derimod svaret, regner han med at der vil komme endnu et spørgsmål som vedrører det propositionelle indhold, og derfor svarer han med det samme på det og undlader eksplicit at svare på det første som i (49a), hvorimod han i (49b) svarer på det stillede spørgsmål og går videre med oplysningen om Peters helbredstilstand, et svarmønster der genfindes i italiensk:

(49) - Ved De om Peter er syg?

(49a) - Nej, det er han ikke.

(49b) - Ja. Det er han ikke.

Face-saving er et vigtigt element i al kommunikation, men måske især i spørgsmål-svar, da de to kommunikationsparter skal samarbejde om en tekstsekvens. Såvel intra- som interlingvistisk er det et meget spændende aspekt, der i $\varnothing v$ vrigt sprogligt har en del til fælles med meningsudveksling, men emnet er for stort til at blive behandlet her.

22 Jf. Brown \& Levinson (1987). 


\section{Spørgsmål-svar-konstruktionen set som tekstsekvens}

I afsn. 2 koncentrerede vi os især om syntaktisk/strukturelle fænomener og argumenterede for at fortolke spørgsmål-svar som en kompleks sætning, og i afsn. 3 behandlede vi især modale aspekter. I dette afsnit vil vi ud fra et samlet semantisk, pragmatisk og syntaktisk synspunkt argumentere for at spørgsmålet + det samlede svar, bestånde af flere sætninger eller sætningsemner, meget ofte kan anskues som én tekstsekvens.

Ved tekstsekvens forstår vi en tekstenhed med selvstondig tekstuel funktion, dvs. en tekststreng med et selvstændigt semantisk/pragmatisk, makropropositionelt indhold ${ }^{23}$. En tekstsekvens består af en nuklearog (evt.) en eller flere satellitdele. Nukleardelen repræsenterer sekvensens centrale budskab, satellitdelene tilføjer uddybende forklaringer, baggrundsinformation etc. Satellitdelene vil ofte ikke give mening uden nukleardelen, eller vil i hvert fald normalt være kommunikativt dårligt motiveret, hvorimod nukleardelen generelt vil viderebringe et budskab også uden satellitdelene 24 .

\subsection{Adækvate svar}

I afsn. 2 ovenfor skelnede vi mellem svartypers strukturelle og pragmatiske markerethed. Vi opfattede de anaforiske og elliptiske svar som strukturelt umarkerede, og de svar som opfylder spørgers forventning om at få svar på sit spørgsmål, som pragmatisk umarkerede eller adcekvate.

Adækvate svar vil normalt bestå af det i spørgsmålet præsupponerede element (ved Enten-Eller sandhedsværdien, ved X den rematiske størrelse svarende til spørgeordet) samt evt. en uddybende tilføjelse. I "kanoniske" tilfælde af sekvenser med spørgsmål + adækvate svar kan spørgsmålet sammen med første del af svaret således opfattes som tekstsekvensens nukleardel; her formidles det centrale budskab. Den følgende del af svaret kan derimod ses som en satellit, der kan indeholde uddybende forklaringer, eksemplifikationer, argumentation,

23 Jvf. Rigotti (1993: 61), Korzen (1997: 133-134) og Korzen (under udgivelse). For en mere udførlig behandling af de i dette afsnit omtalte fænomener, se Jensen/ Korzen/Skytte (under udarbejdelse).

24 Jvf. også Matthiessen/Thompson (1988: 287-292) og Jensen/Korzen/Skytte (1995: 75-81). 
begrundelse, genoptagelse af belæg etc., bl.a. afhængigt af den teksttype dialogen kan henføres til.

De sproglige kohæsionselementer der medvirker til at skabe informationssammenhængen mellem nuklear og satellit, udgøres af forskellige former for referentiel og tematisk kohærens, fx anaforiske udtryk (pro-former og ellipser), substitution, reformulering og brug af vikarverber, samt implicit og eksplicit konnexion. Den referentielle kohærens vil normalt ytre sig bl.a. ved topisk kontinuitet, dvs. fastholdelse af det samme topic i spørgsmål og svar. Topic er i de fleste tilfælde grammatikaliseret som sætningens subjekt ${ }^{25}$.

I autentiske eksempler som de følgende kan det kursiverede opfattes som svarets nukleardel, og resten af svaret kan ses som uddybende satellitdele:

(50) Lizzie: [...] Sig mig, er det rigtigt du tænkte på at få dig et job?

Bella: Hmjah ... Jeg har jo så meget tid nu. (Bella 24)

(51) Børsens Nyhedsmagasin: Væsentlige flaskehalsproblemer tror du ikke på?

Palle Simonsen: "Nej, det gør jeg ikke. Ganske vist vil der være eksempler i visse brancher og i visse dele af landet. Men grundlæggende vil flaskehalsene kunne holdes fra livet under to forudsætninger. Første betingelse er, at det arbejdsmarkedspolitiske system er tilstrækkeligt fleksibelt i forhold til behovene. Anden betingelse er, at virksomhederne i langt større udstrækning informerer tidligt til arbejdsformidlingen. Man kan ikke altid forvente, at AF kan skaffe medarbejdere fra den ene dag til den anden". (Børsens Nyhedsmagasin 11.2.94).

(52) A: Il lavoro di una giornata tipica quale può essere?

B: Mah, il mio lavoro è molto vario, diciamo le cose di cui mi devo occupare alla scuola sono tante: dall'approvigionamento dei materiali, quindi comprare quello che serve, tutto quello che può servire nella scuola, alla pubblicità, all'organizzazione dei corsi, gli insegnanti, test di ammissione ai corsi, quindi diciamo è molto vario. (Scene, p. 11)

(53) A: Certo, e quali vantaggi offriva la scuola svizzera rispetto a una scuola italiana?

25 Jvf. Korzen (1997) og (under udgivelse). Topisk kontinuitet er dog ikke til stede i de $\mathrm{X}$-spørgsmål hvor det rematiske element netop er subjektet, der følgelig nyintroduceres i svaret. 
B: Mah, nessuno in particolare diciamo. Un vantaggio certamente ce l'ha: è che la scuola svizzera a Roma è una scuola piccola, è come una piccola famiglia, perché hanno fra bambini dell'asilo fino al liceo, alla maturità, ci sono circa 300 studenti, che sono pochi rispetto ai 2, 3, 4 mila studenti che ogni istituto pubblico ha a Roma. E poi sono seguiti molto da vicino, si conoscono tutti e questo è un vantaggio, almeno noi lo troviamo un vantaggio. (Scene, p. 12)

I alle fire eksempler ses spørgsmålets topic/subjekt videreført som topic/subjekt i svaret. I (50) indeholder svarets nukleardel alene den præsupponerede sandhedsværdi, og denne begrundes i satellitten. I (51) ses sandhedsværdimarkøren i svaret, $N e j$, udvidet med det semantisk betydningstomme det g $\phi r$ jeg ikke, hvor anaforen det og vikarverbet $g \phi r$ blot genoptager de leksikalske elementer i spørgsmålet, og samlet kan Nej, det gør jeg ikke opfattes som svarets nukleardel. De to første sætninger i den følgende satellit indeholder bl.a. en ellipse (eksempler $[\emptyset] i$ visse brancher, $[\emptyset] \rightarrow$ på flaskehalsproblemer) og en definit NP (flaskehalsene), begge med anaforisk henvisning til sproglige elementer i spørgsmålet, og de to følgende sætninger i samme svar indeholder genoptagelser af NP'en to forudsatninger med leksikalsk substitution: Første betingelse og Anden betingelse. Den sidste sætning i svaret er knyttet til de foregående ved implicit konnexion, der mangler et for/thi.

I (52) specificeres topic/subjekt ved en fuld NP-genoptagelse, præciseret ved mio, i svarets nukleardel. Herefter følger en reformulering med substitution af subjektet (il mio lavoro $\rightarrow$ le cose di cui mi devo occupare alla scuola), og subjektsprædikatet tante uddybes/eksemplificeres i dall'approvigionamento ... test di ammissione ai corsi. Den sidste sætning i svaret, quindi diciamo è molto vario, afrunder og understreger satellittens funktion som begrundelse for nuklearsætningen ved simpelt hen at gentage nuklearsætningen (omend med anaforisk $\emptyset$-subjekt) efter konnektoren quindi ${ }^{26}$.

I (53) indeholder nukleardelen af svaret det i spørgsmålet præsupponerede rematiske element (nessuno in particolare), og den følgende satellit benyttes til at præcisere/korrigere denne nuklear. Satellitten viderefører såvel spørgsmålets subjekt (la scuola svizzera, udtrykt ved Øsubjekt i ce l'ha) som dets tematiske element (udtrykt i un vantaggio,

26 Sådanne afsluttende og opsummerende gentagelser, jvf. et tilsvarende eksempel i (53), er ganske typiske ved længere svar - især i argumentative teksttyper. 
jvf. quali vantaggi i spørgsmålet), og de følgende sætninger, til og med si conoscono tutti, fungerer som prædikat til, dvs. yderligere specificering af, un vantaggio. Herefter indkapsler pronominet questo beskrivelsen, og un vantaggio gentages som prædikat hertil. Satellitten afsluttes med en reformulation af konklusionen questo è un vantaggio.

Det ses således i alle de fire tilfælde at satellitdelen af svaret genoptager eller henviser til elementer i nukleardelen, dvs. spørgsmålet + den del af svaret der umiddelbart indeholder det i spørgsmålet præsupponerede element, og satellitterne er ikke eller vanskeligt kommunikativt fortolkelige uden nuklearerne. Dette forhold berettiger til at opfatte den samlede spørgsmål-svar-streng som én tekstsekvens.

En forventet nukleardel af et svar, en sandhedsværdi- eller modalitetsmarkør eller (uden tvivl sjældnere) det rematiske element svarende til spørgeordet, kan være udeladt, når svareren i og med en uddybende satellit (i (54)-(55) kursiveret) finder den overflødig:

(54) Bella: Gud ... hvor ved du fra han er Ridder?

Jacob: Jeg har slået ham op i den blå bog.

Bella: Den blå ...? Kender du den?

Jacob: Fabian har en. Sommetider læser vi højt af den. (Bella 15)

(55) Ravn: Jeg ville aldrig drømme om at anfægte Deres motiver, direktør Berg ... jeg mener, Deres firma og Deres navn borger jo for at der foreligger seriøse grunde ...

Martin: Hvad? Nå ja ... Men De skal vel have de forskellige data?

Ravn: Tak, men det ordner fru Malm. Vi mente det var mest hensynsfuldt overfor Dem at gøre det på den måde. (Bella 3536).

I de følgende sætninger i de to svar bemærkes henh. anaforen [laeser vi højt af] den og vikarverbum + anafor gфre det, der alle er eksempler på kohæsionen til den foregående ko-tekst.

Strukturelt umarkerede svar kan opfattes som stærkest knyttede til spørgsmålet. Her er afhængigheden "gensidig": indholdsmæssigt præsupponerer de to dele hinanden (jvf. afsn. 2), og formelt udtrykker proformer og ellipser i svaret en anaforisk henvisning til spørgsmålet. I fulde svar der er indledt af et svarord $J a, N e j$, Måske osv., er dette med til tilsvarende at udtrykke en tilknytning til spørgsmålet. 
Et fuldt svar der ikke er indledt af et svarord, udtrykker derimod ikke nogen formel tilknytning til spørgsmålet ud over de sproglige kohæsionselementer som set i (50)-(53). Forbindelsen etableres således alene ved denne kohæsion samt ved spørgsmålets formelle og pragmatiske "uafsluttethed". Et fuldt svar uden svarord vil ofte kunne fungere som mere eller mindre selvstændig replik; jvf. det flg. eksempel, hvor den tematiske kohærens bl.a. er udtrykt af de kursiverede NP'er:

(56) Har opsvinget allerede så meget fart, at det arbejdsmarkedspolitisk set ikke er tilrådeligt at gennemføre endnu en finanspolitisk lempelse?

"Den førte finanspolitik har fåt fuld accept af markedet. Det er klarest dokumenteret ved rentefaldet og kronens værdi. Det viser tydeligt at den finanspolitiske lempelse ikke har været for stor. Det er ikke min fornemmelse at nogen opererer med yderligere finanspolitiske lempelser." (Børsens Nyhedsmagasin 11.2.94)

Med et fuldt svar af denne type kan taler således markere en vis pragmatisk afstandtagen til spørger og/eller spørgsmål, og denne svartype forekommer ofte i argumenterende teksttyper.

Også et spørgsmål kan være udvidet med satellit. En sådan satellit kan fx udtrykke årsagen til eller baggrunden for at spørgeren stiller sit spørgsmål:

Dove hai messo Anna Karenina? Lo vuole Piero.

Che t'ha detto Emma? La sentivo gridare. (begge cit.: Stati 1982: 116)

eller et forbehold for at spørgsmålet fx kan være for vanskeligt at besvare:

(58) M: E come ci vedono loro [= i danesi]? Non so se lei è riuscito a capire come siamo visti da loro.

$\mathrm{R}$ : Ma guardi, i nostri rapporti sono..., non sono molto profondi, non vanno molto in profondità. [...] (Scene, p. 58)

\subsection{Ikke-adækvate svar}

Ikke-adækvate svar er replikker, der ikke indfrier spørgers pragmatiske forventning om at få svar på sit spørgsmål, dvs. som ikke afslutter tekstsekvensen med den i spørgsmålet præsupponerede størrelse. Analysen af sekvensforholdene afhænger her af de enkelte svartyper og vil i denne sammenhæng af pladshensyn kun blive berørt ganske summarisk. 
Afhængigt af graden af tilknytning til spørgsmålet kan ikke-adækvate svar inddeles i tre hovedtyper:
A. svartypen Det ved jeg ikke / Non lo so
B. metalingvistiske og metakommunikative spørgsmål
C. replikker der markerer emneskift.

A. Svartypen Det ved jeg ikke / Non lo so (med dens mange varianter) er strukturelt set umarkeret. Det ubetonede (og NB: invariable) objektspronomen det / lo genoptager hele spørgsmålet og markerer den snævre tilknytning hertil. Dette svar vil ikke være fortolkeligt uden spørgsmålet og er at opfatte som en del af samme sekvens som dette. Det italienske lo kan - i modsætning til det danske det - udelades ved anaforisk ellipse, og man kan svare Non so.

B. Metalingvistiske og metakommunikative spørgsmål kan fx gå på betydningen henh. brugen i kommunikationen af et bestemt udtryk, dvs. på et element af langue henh. et element af parole; et eksempel på sidstnævnte:

(59) Konrad: [...] Syns du jeg ska' la’ Victor gå fallit?

Bella: Hvad? Victor?

Konrad: Ja, Victor. Hør, vil du ikke ha' noget at drikke? (Bella 45)

eller de kan gå på berettigelsen af eller årsagen til det samlede spørgsmål (jvf. kommentaren til eks. (34)):

(60) Bella [...]: Hvor bor du?

Jacob: Hvorfor vil du vide det? (Bella 22)

I begge tilfælde er der såvel formelt (leksikalsk gentagelse henh. anafor) som tematisk en klar tilknytning til det oprindelige spørgsmål, og det indskudte metasproglige/-tekstuelle spørgsmål vil ikke være fortolkeligt alene. På den anden side ændrer indskuddet kommunikationsforløbet og udgør sin egen kommunikative enhed. Indskudte spørgsmål som i (59)-(60) vil ofte udgøre begyndelsen af en sekvens, der siden afsluttes med svaret på det indskudte spørgsmål, i (59) Ja, Victor. Man kunne her tale om indlejrede tekstsekvenser, en særlig sekvenstype som befinder sig inden for og underordnet (og snævert tilknyttet) en anden sekvens.

C. Emneskiftet (Stati (1982: 62): "la non-replica") udtrykker den løseste tilknytning til den foregående tekst. Her markerer modtager at 
han hverken ønsker at besvare spørgsmålet eller bruge det som referenceramme og påbegynder i stedet en ny tekstsekvens, i det flg. eksempel med et retorisk spørgsmål (Ka' man overhovedet ikke tale med dig?). Det oprindelige spørgsmål (Hvorfor vil du vide det?) kommer til at stå som en uafsluttet tekstsekvens hvis præsupponerede del udebliver:

(61) Bella [...]: Hvor bor du?

Jacob: Hvorfor vil du vide det? [metakommunikativt spørgsmål, indskudt sekvens]

Bella: $\mathrm{Ka}$ ' man overhovedet ikke tale med dig? [emneskift; ny sekvens] (Bella 22)

\section{Kort sammenfatning og perspektivering}

Vi har i vores artikel ønsket at påvise det hensigtsmæssige, såvel deskriptivt som didaktisk, i at fortolke spфrgsmål-svar som en sammenhængende tekstenhed svarende til en kompleks sætning eller - i tilfælde, hvor konstruktionen omfatter flere sætninger eller sætningsemner - som en tekstsekvens. Fortolkningen bygger på syntaktiske, semantiske og pragmatiske argumenter.

Fremstillingen har af pladshensyn været koncentreret om prototypiske konstruktioner på dansk og italiensk, idet vi dog ved gennemgangen har påpeget eksistensen af mere specifikke problemstillinger, som vi i en kommende publikation (Jensen/Korzen/Skytte, under udarbejdelse) vil gøre til genstand for en mere detaljeret beskrivelse. Det drejer sig fx om restriktioner for brug af vikarverber på de to sprog, absolut brug af modalverber, de forskellige sprogbrugsbestemte svartyper på de to sprog, de varierende sproglige udtryk for afsender-/modtagerattituder (som fx face-saving), ikke-adækvate svar (som fx det ved jeg ikke, metalingvistiske- og metakommunikative spørgsmål og replikker, som markerer emneskift), samt tekstsekvensers strukturering afhængigt af teksttypologi, herunder indlejring af mindre tekstsekvenser i større tekstsekvenser.

Mange af de nævnte emner har hidtil fortrinsvis været behandlet $\mathrm{i}$ pragmalingvistiske fremstillinger, specielt inden for konversationsanalyse, og normalt med henblik på et enkelt sprog. Vi peger på behovet for en komparativ beskrivelse der omfatter strukturelle ligheder og forskelle mellem to eller flere sprog, og som dermed kan bidrage til en styrkelse af sprogdidaktiske arbejder. 


\section{Bibliografi}

Benveniste, Émile (1966): Problèmes de linguistique générale. Paris: Gallimard.

Brown, Penelope \& Stephen C. Levinson (1987) [1978]: Politeness. Some universals in language use. Cambridge: Cambridge University Press.

Cherchi, Lucien (1985): On the role of Ellipsis in discourse coherence. In: MeyerHermann, Reinhard und Rieser, Hannes (Hrsgg.), Ellipsen und fragmentarische Ausdrücke, Band 2. Tübingen, Max Niemeyer Verlag.

Cramer, Jens et al. (1996): 699 varme termer. Leksikon til sprogkundskab. Aarhus: Aarhus Universitetsforlag.

Diderichsen, Paul (1962): Elementar Dansk Grammatik. København: Gyldendal. 3. udgave (1. udgave 1946).

GGIdC = Grande Grammatica Italiana di Consultazione I-III (1988-1995) a cura di Lorenzo Renzi et al. Bologna: Il Mulino.

Gil, Alberto (1995): Textadverbiale in den romanischen Sprachen. Frankfurt am Main: Peter Lang.

Grice, Paul (1975): Logic and conversation. In: Peter Cole \& Jery Morgan (eds). Speech Acts. Syntax and Semantics 3. New York: Academic Press.

Halliday, M.A.K./Hasan, Ruqaiya (1976): Cohesion in English, London: Longman.

Jansen, Hanne/Jensen, Bente Lihn/Jensen, Eva Skafte/Korzen, Iørn/Polito, Paola / Skytte, Gunver/Strudsholm, Erling (under udgivelse, a): Testi paralleli scritti e orali, in italiano e danese. Strategie narrative. Cuadernos de filología italiana. Madrid.

Jansen, Hanne/Jensen, Bente Lihn/Jensen, Eva Skafte/Korzen, Iørn/Polito, Paola/ Skytte, Gunver/Strudsholm, Erling (under udgivelse, b): Tekststrukturering på italiensk og dansk. Resultater af en komparativ undersøgelse. København: Museum Tusculanum.

Jensen, Bente Lihn (1997): Om modalitet. In: Jakobsen, Lisbeth Falster/Skytte, Gunver (eds.): Ny forskning i grammatik. Fallespublikation 4. Odense: Odense Universitetsforlag.

Jensen, Bente Lihn/Korzen, Iørn/Skytte, Gunver (1995): Tekst, teksttypologi og tekstækvivalens i kontrastivt perspektiv. In: Durst-Andersen, Per og Nørgård-Sørensen, Jens (eds.): Ny forskning i dansk grammatik. Igangsat af Statens Humanistiske Forskningsråd. Fællespublikation 2. Liselejesymposiet. Odense Universitetsforlag.

Jensen, Bente Lihn/Korzen, Iørn/Skytte, Gunver (under udarbejdelse): Sprogbrug italiensk - dansk komparativt. En undersфgelse af italiensk sprogbrug sammenlignet med dansk.

Jensen, Jørgen Schmitt (1970): Subjonctif et hypotaxe en italien. Odense: Odense University Press.

Korzen, Iørn (1996): L'articolo italiano fra concetto ed entità, I-II. København: Museum Tusculanum. 
Korzen, Iørn (1997): Topisk kontinuitet og tekststrukturering på italiensk og dansk. In: Jakobsen, Lisbeth Falster/Skytte, Gunver (eds.): Ny forskning i grammatik. Igangsat af Statens Humanistiske Forskningsråd, 4. Odense Universitetsforlag.

Korzen, Iørn (under udgivelse): Tekststruktur og anafortypologi In: Jansen et al. (under udgivelse, b).

Lundquist, Lita (1983): Pragmatiske aspekter. In: Tekstlingvistik: Teorier og analyser. Ark 16 pp. 5-20. Handelshøjskolen i København.

Lyons, John (1995): Linguistic Semantics: An Introduction. Cambridge: Cambridge University Press.

Matthiessen, Christian/Thompson, Sandra A. (1988): The structure of discourse and 'subordination'. In: Haiman, John/Thompson, Sandra A. (eds.): Clause Combining in Grammar and Discourse. Amsterdam/Philadelphia: John Benjamins Publishing Company.

Renzi, Lorenzo (1988): GGIdC (Grande grammatica italiana di consultazione). Volume I. Bologna: Il Mulino.

Salvi, Giampaolo/Vanelli, Laura (1992): Grammatica essenziale di riferimento della lingua italiana. Firenze: Le Monnier.

Searle, John (1975): A taxonomy of illocutionary acts. In: Gundersen, K. (ed.): Language, Mind and Knowledge. Minnesota.

Shopen, Timothy (ed.) (1985): Language typology and syntactic description vol I-III. Cambridge: Cambridge University Press.

Skytte, Gunver/Jensen, Bente Lihn/Korzen, Iørn (1993): Italiensk Sprogbrug. Projektbeskrivelse. In: Ny forskning i grammatik. Igangsat af Statens Humanistiske Forskningsråd. Odense Universitetsforlag.

Skytte, Gunver (1995a): Dialogen i oversættelse. In: Danske Afhandlinger om Oversattelse. Oversattelse af Litteratur 6. København.

Skytte, Gunver (1995b): "Translating answers: a case of transparency." In: Perspectives. Studies in Translatology 2. Museum Tusculanum Press. University of Copenhagen.

Skytte, Gunver (1996): Per una grammatica della risposta. In: Benincà, Paola/Cinque, Guglielmo/De Mauro, Tullio/Vincent, Nigel (a cura di): Italiano e dialetti nel tempo. Saggi di grammatica per Giulio C. Lepschy. Roma: Bulzoni.

Stati, Sorin (1982): Il dialogo. Considerazioni di linguistica pragmatica. Napoli: Liguori.

Togeby, Ole (1993): Praxt. Aarhus: Aarhus Universitetsforlag.

\section{Eksempelbibliografi}

Børsens Nyhedsmagasin 11.2.94. (Interview med Palle Simonsen).

Korzen, Iørn (1995): Scene italiane. 27 videosekvenser til undervisning i italiensk. Handelshøjskolen i København. Afdelingen for Italiensk. 
Machiavelli, Niccolò (1959): La Mandragola. Milano: Rizzoli. (Skrevet mellem 1512 og 1520).

Moravia, Alberto (1991): La donna leopardo. Milano: Bompiani. Dansk oversættelse (1993): Leopardkvinden. Oversat af Ulla Kampmann. Holkenfeldt.

Panduro, Leif (1971): Bella og Et godt liv. To TV spil. Gyldendals Tranebøger. 
